\title{
Repeated-batch ethanol fermentation from sweet sorghum juice by free cells of Saccharomyces cerevisiae NP 01
}

\author{
Pongthep Ariyajarearnwong ${ }^{1}$, Lakkana Laopaiboon ${ }^{2,3 \star}$, Prasit Jaisil ${ }^{4}$ and Pattana Laopaiboon ${ }^{2}$ \\ ${ }^{1}$ Graduate School, Khon Kaen University, Khon Kaen 40002, Thailand. \\ ${ }^{2}$ Department of Biotechnology, Faculty of Technology, Khon Kaen University, Khon Kaen 40002, Thailand. \\ ${ }^{3}$ Fermentation Research Center for Value Added Agricultural Products, Khon Kaen University, Khon Kaen 40002, \\ Thailand. \\ ${ }^{4}$ Department of Plant Science and Agricultural Resources, Faculty of Agriculture, Khon Kaen University, Khon Kaen \\ 40002, Thailand.
}

Accepted 7 September, 2011

\begin{abstract}
Low-cost inoculum preparation (IP) media for ethanol production were developed. It was found that sweet sorghum juice (SSJ) containing $100 \mathrm{~g} \mathrm{I}^{-1}$ of total sugar without nutrient supplement could be used as the low-cost IP medium instead of the typical IP medium or yeast extract malt extract (YM) medium. Ethanol production from the SSJ (total soluble solids of $24^{\circ} \mathrm{Bx}$ ) by the inoculum of Saccharomyces cerevisiae NP 01 in batch and repeated-batch fermentations was then investigated. The fermentations were carried out under static condition in $500 \mathrm{ml}$ air-locked Erlenmeyer flasks at $30^{\circ} \mathrm{C}$ and the initial yeast cell concentration was $1 \times 10^{8}$ cells $\mathrm{ml}^{-1}$. In the batch fermentation, the concentration $(P)$, productivity $\left(Q_{p}\right)$ and yield $\left(Y_{p / s}\right)$ of ethanol were $110.09 \pm 0.81 \mathrm{~g} \mathrm{l}^{-1}, 2.29 \pm 0.01 \mathrm{~g}^{-1} \mathrm{~h}^{-1}$ and $0.51 \pm 0.02$, respectively. In the repeated-batch fermentation, the yeasts could be used at least eight successive batches without a marked decrease in ethanol production. The repeated-batch fermentation with fill and drain volume at $75 \%$ of the working volume gave higher ethanol production efficiencies than those at $50 \%$ of the working volume in terms of total ethanol production rate $\left(\mathrm{g} \mathrm{h}^{-1}\right)$. The average $P, Q_{p}$ and $Y_{p / s}$ of the eight successive batches at $75 \%$ fill and drain volume in a $2 \mathrm{~L}$ bioreactor at the agitation rate of 100 rev $\min ^{-1}$ were $93.30 \pm 9.44 \mathrm{~g} \mathrm{l}^{-1}, 1.21 \pm 0.43 \mathrm{~g} \mathrm{l}^{-1} \mathrm{~h}^{-1}$ and $0.48 \pm 0.03$, respectively.
\end{abstract}

Key words: Repeated-batch, ethanol fermentation, low-cost nutrient, sweet sorghum juice, Saccharomyces cerevisiae.

\section{INTRODUCTION}

Nowadays, the ethanol industry utilizes raw materials rich

${ }^{*}$ Corresponding author. E-mail: lakcha@kku.ac.th. Tel: +66 43 362121 , Fax: +66 43362121.

Abbreviations:IP, Inoculum preparation; YM, yeast extract malt extract; $\boldsymbol{Q}_{\boldsymbol{p}}$, ethanol productivity; $\boldsymbol{P}$, ethanol concentration; $\boldsymbol{Y}_{\boldsymbol{p} / \boldsymbol{s}}$, ethanol yield; YE, yeast extract; ME, malt yeast; $\mathbf{P E}$, peptone; DNS, dinitrosalicylic acid; GC, gas chromatography; DSY, dried spent yeast; $\mu$, specific growth rate; SSJ, sweet sorghum juice. in saccharides such as sugar cane or sugar beets and raw materials rich in starch such as corn and wheat (Rudolf et al., 2009). In Thailand, the main raw materials used for ethanol production are sugarcane molasses and cassava. Regarding the energy policy of the Thai government, ethanol production will be increased to $3,000,000 \mathrm{~L}_{\text {day }}{ }^{-1}$ in year 2012 and to $9,000,000 \mathrm{~L} \mathrm{day}^{-1}$ in year 2022 (Department of Energy Business, 2010). Therefore, it is possible that Thailand may face a shortage of sugar cane molasses and cassava.

Sweet sorghum [Sorghum bicolor (L.) Moench] is a high biomass- and sugar-yielding C4 plant (Bryan, 1990) containing high fermentable sugars and insoluble 
carbohydrates (cellulose and hemicellulose) (Bennett and Anex, 2009). Its grain and stem can be used as substrates for the production of sugar, alcohol syrup, fodder, fuel, bedding, roofing, fencing and paper (Rajvanshi and Nimbkar, 2005). Due to the energy crisis, renewable carbohydrate materials including sweet sorghum have become more of interest for biological transformation into ethanol for use as fuel or fuel additive (Göksungur and Zorlu, 2001). Sweet sorghum has been noted for its potential as an energy crop because it can be cultivated at almost all temperature and tropical climate areas (Bennett and Anex, 2009) with the growing period of 120 to 150 days (Wu et al., 2010). The juice from the stalks contains many essential trace elements for microbial growth and ethanol production (Dajui, 2010; Laopaiboon et al., 2009). In addition, the $\mathrm{pH}$ of the juice is in the range of the optimum $\mathrm{pH}$ for yeast growth and ethanol production ( $\mathrm{pH} 4.0$ to 5.5) (Narendranath and Power, 2005).

One of the key concepts to achieve high ethanol production efficiency is based on a high cell concentration because the ethanol productivity is proportional to the biocatalyst concentration during ethanol fermentation (Ikegami et al., 1998). Saccharomyces cerevisiae is one of the main biocatalysts or ethanolproducing organisms used in industrial processes. In typical ethanol fermentation, the yeast cells are cultured in yeast extract-malt extract (YM) medium. However, the prices of the YM medium compo-nents such as glucose, yeast extract, malt extract and peptone are relatively expensive. To minimize the cost of inoculum preparation (IP) medium, low-cost substrates and/or nutrient supplements such as sweet sorghum juice (SSJ) (Dajui, 2010; Laopaiboon et al., 2009) and dried spent yeast (DSY) (Sridee et al., 2009; Ferreira et al., 2010) may be used instead of the expensive components.

Apart from the development of new sweet sorghum cultivars with high grain and sugar yield (Almodares et al., 2007), fermentation process development is also important for efficient ethanol production from SSJ (Laopaiboon et al., 2007). In this study, we are interested in repeated-batch fermentation because this process has several advantages compared to conventional batch fermentation such as no new inoculum requirement for each batch (Bajpai and Bajpai,1988) and long-term productivity (Anastassiadis and Rehm 2006). In addition, no time is wasted for cleaning and resterilization, and the operational control is easier than that of a continuous mode.

Repeated-batch fermentation is the fermentation that the portion of the fermentation broth is withdrawn at time intervals, and the residual part of the broth is used as an inoculum for the next batch. The repeated-batch process has been used to improve several bio-product formation such as citric acid (Anastassiadis and Rehm, 2006), hydrogen (Poggi-Varaldo et al., 2009), L-lactic acid (Akao et al., 2007; Wu and Jiang, 2009) and ethanol (Choi et al., 2009; Ma et al., 2009; Staniszewski et al., 2009). The main important factors affecting the production efficiency in the repeated-batch process are cell concentration, fermentation time and recycling volume (Chen et al., 2008; Choi et al., 2009; Staniszewski et al., 2009).

The aim of this study was to develop a low-cost IP medium for ethanol production and to improve ethanol production efficiency from SSJ using repeated-batch fermentation (fill and drain technique) by $S$. cerevisiae NP 01 . The effects of fill and drain volume in the repeatedbatch system on ethanol production were also investigated.

\section{MATERIALS AND METHODS}

\section{Composition of nutrient supplements}

The main composition of sweet sorghum, yeast extract (YE) and DSY was analyzed by Central Laboratory (Thailand) Co., Ltd., Khon Kaen, Thailand.

\section{Microorganism, inoculum preparation, inoculum preparation} (IP) medium

S. cerevisiae NP 01 isolated from Loog-pang (Chinese yeast cake) from Nakorn Panom province, Thailand, was inoculated into a 250 $\mathrm{ml}$ Erlenmeyer flask containing $150 \mathrm{ml}$ of $\mathrm{YM}$ medium as the first medium. The medium contained (in $\mathrm{g} \mathrm{l}^{-1}$ ) YE 3, malt extract (ME) 3, peptone (PE) 5 and glucose 10. The flask was incubated on a rotating shaker at $150 \mathrm{rev} \mathrm{min}^{-1}, 30^{\circ} \mathrm{C}$ for $15 \mathrm{~h}$.

To increase cell concentration, the yeasts (10\% inoculum size) were transferred into $500 \mathrm{ml}$ Erlenmeyer flasks with $350 \mathrm{ml}$ of modified IP media as shown in Table 1. The flasks were further incubated under the conditions previously mentioned and the viable yeast cell concentration was measured every $3 \mathrm{~h}$ for $24 \mathrm{~h}$. Specific growth rate $(\mu)$ of the yeasts in the IP media was calculated. The IP medium giving the highest $\mu$ was used for inoculum preparation for ethanol production.

\section{Raw materials}

SSJ cV. KKU40 modified from cv. Keller was obtained from the department of Agronomy, Faculty of Agriculture, Khon Kaen University, Thailand. After extraction, the juice containing total soluble solids of $18^{\circ} \mathrm{Bx}$, was concentrated to $75^{\circ} \mathrm{Bx}$ and kept at $18^{\circ} \mathrm{C}$ until use. DSY obtained from Beerthip Brewery (1991) Co., Ltd., Bang Baan, Phra Nakhon Sri Ayutthaya, Thailand was kept at room temperature until use.

\section{Ethanol production medium}

The concentrated SSJ was diluted with distilled water to the total soluble solids of $24^{\circ} \mathrm{Bx}$ and used as an ethanol production medium. The ethanol production medium was transferred into a $500 \mathrm{ml}$ airlocked Erlenmeyer flask (working volume of $400 \mathrm{ml}$ ) or a $2 \mathrm{~L}$ bioreactor (working volume of $1500 \mathrm{ml}$ ) and autoclaved at $110^{\circ} \mathrm{C}$ for 15 (for the $500-\mathrm{ml}$ flask) or $28 \mathrm{~min}$ (for the $2 \mathrm{~L}$ bioreactor) (Laopaiboon et al., 2009).

\section{Fermentation processes}

\section{Batch fermentation system}

The yeasts grown in the optimum IP medium were inoculated into 
Table 1. Composition of yeast inoculum preparation (IP) media.

\begin{tabular}{ll}
\hline Medium code $^{*}$ & Composition $\left(\mathbf{g ~ l}^{-1}\right)$ \\
\hline YM 1 (control 1) & YE 3, ME 3, PE 5 and glucose 20 \\
YM 2 (control 2) & YE 3, ME 3, PE 5 and glucose 100 \\
SSJ 1 & SSJ containing total sugar of 20 (SSJ 20) \\
SSJ 2 & SSJ 20 and DSY 11 \\
SSJ 3 & SSJ 20, YE 1.5, ME 1.5 and PE 2.5 \\
SSJ 4 & SSJ containing total sugar of 100 (SSJ 100) \\
SSJ 5 & SSJ 100 and DSY 11 \\
SSJ 6 & SSJ 100, YE 1.5, ME 1.5 and PE 2.5 \\
\hline
\end{tabular}

* YM, Yeast extract malt extract medium; SSJ, sweet sorghum juice; YE, yeast extract; ME, malt extract; PE, peptone; DSY, dried spent yeast.

the sterile ethanol production medium in the $500 \mathrm{ml}$ air-locked Erlenmeyer flask to give the initial cell concentration of $1 \times 10^{8}$ cells $\mathrm{ml}^{-1}$. The fermentation was operated at $30^{\circ} \mathrm{C}$ under static condition. The samples were collected at time intervals for analysis.

\section{Repeated-batch fermentation system}

The repeated-batch system in the $500 \mathrm{ml}$ flask was first carried out in batch mode as described above. When the total residual sugars in the broth had dropped slowly as found in the batch fermentation system, the fermented broth was withdrawn at 75 and $50 \%$ of the working volume and the same amount of the fresh juice was immediately replaced to initiate the next batch. This method was called "fill and drain technique" (Anastassiadis and Rehm, 2006). Eight successive batches were performed. The fill and drain volume giving the maximum ethanol production was selected for the fermentation in the $2 \mathrm{~L}$ bioreactor.

In the $2 \mathrm{~L}$ bioreactor, the fermentation was operated as in the flask, but the medium was agitated at $100 \mathrm{rev} \mathrm{min}^{-1}$. Eight successive batches were performed.

\section{Analytical methods}

The cell numbers and the total soluble solids in the fermentation broth were determined by direct counting method using haemacytometer with methylene blue staining technique and handheld refractometer (Zoecklien et al., 1995), respectively. The $\mu$ was calculated from the slope of natural log viable cell concentration in log phase against time. The fermentation broth was centrifuged at

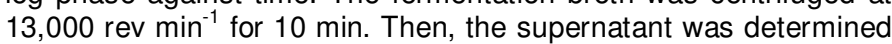
for residual total sugar and reducing sugar by phenol-sulfuric acid method (Mecozzi, 2005) and dinitrosalicylic acid (DNS) method (Bailey, 1988), respectively. Ethanol concentration $(P)$ was analyzed by gas chromatography (Shimadzu GC-14B, Japan, solid phase: polyethylene glycol (PEG-20M), carrier gas (200 KPa): nitrogen, $150^{\circ} \mathrm{C}$ isothermal packed column, injection temperature $180^{\circ} \mathrm{C}$, flame ionization detector temperature $250^{\circ} \mathrm{C}$; gas chromatography (GC) solution analysis Version 2.30) and 2propanol was used as an internal standard (modified from Laopaiboon et al., 2007). The ethanol yield $\left(Y_{p / s}\right)$ was calculated and expressed as $g$ ethanol produced per $g$ sugar utilized $\left(\mathrm{g} \mathrm{g}^{-1}\right)$. The volumetric ethanol productivity $\left(Q_{p}, \mathrm{~g} \mathrm{I}^{-1} \mathrm{~h}^{-1}\right)$ was calculated by the following equation:

$$
Q_{p}=P / t
$$

Where, $P$ is the actual ethanol concentration produced $\left(\mathrm{g} \mathrm{I}^{-1}\right)$ and $t$ is the fermentation time (h) giving the highest $P$ for batch and repeated-batch fermentations.

\section{RESULTS AND DISCUSSION}

\section{Composition and cost of nutrient supplements}

Some nutrient components of the concentrated SSJ, YE and DSY are shown in Table 2. The DSY, a by-product from brewery's industry, was evaluated as a complex nitrogen source because it contained high levels of nitrogen and minerals. Total nitrogen content in DSY was about $60 \%$ of that in YE. Potassium, sodium, zinc and chloride contents were much lower than those of $Y E$ whereas calcium, magnesium and iron contents were higher. Other components detected in DSY were comparable with those of yeast extract. In Thailand, the cost of yeast extract (HiMedia laboratory, India) and DSY (Beerthip Brewery (1991), Co., Ltd.) was approximately US\$ 67 and 0.7 per kg, respectively.

Several researches used spent yeast cells, crude yeast autolysate or spent yeast hydrolysate as a nutrient supplement for the production of ethanol (York and Ingram, 1996), lactic acid (Rivas et al., 2004; Marica et al., 2007), succinic acid (Jiang et al., 2009), biomass of Bacillus thuringiensis (Saksinchai et al., 2001), disodium guanosine-5'-monophosphate (5'-GMP) (Sombutyanuchit et al., 2001), S-adenosyl-L-methionine (AdoMet) and glutathione (GSH) (Liu et al., 2004), microbial medium (Zvidzai et al., 2007) and a commercial YE (Tanguler and Erten, 2008).

\section{Growth of S. cerevisiae NP 01 in inoculum preparation media}

We previously studied the effects of glucose concentration on $S$. cerevisiae NP 01 grown in YM medium (Laopaiboon et al., 2008). It was found that the yeasts grown in YM medium containing $150 \mathrm{~g} \mathrm{I}^{-1}$ of glucose gave significantly higher biomass yield than those containing 
Table 2. Some nutrient components of concentrated SSJ cv. KKU40, YE (HiMedia laboratory, India) and DSY from Beerthip Brewery (1991) Co., Ltd., Bang Baan, Phra Nakhon Sri Ayutthaya, Thailand.

\begin{tabular}{lccc}
\hline Component & Concentrated SSJ & Yeast extract & DSY \\
\hline Total soluble solid $\left({ }^{\circ} \mathrm{Bx}\right)$ & 75 & - & - \\
Total $\mathrm{N}(\%)$ & 0.2760 & 10.6500 & 6.4400 \\
Total $\mathrm{P}(\%)$ & 0.1640 & 1.1500 & 1.2500 \\
Total $\mathrm{K}(\%)$ & 5.0550 & 4.9600 & 1.5900 \\
Total $\mathrm{Na}(\%)$ & 0.3940 & 0.8200 & 0.3400 \\
Total $\mathrm{Ca}(\%)$ & 0.0640 & 0.0240 & 0.0670 \\
Total $\mathrm{Mg}(\%)$ & 0.0638 & 0.0540 & 0.1740 \\
Total $\mathrm{Fe}(\%)$ & 0.0004 & 0.0052 & 0.0081 \\
Total $\mathrm{Mn}(\%)$ & 0.0003 & $\mathrm{ND}^{*}$ & $\mathrm{ND}$ \\
Total $\mathrm{Cu}(\%)$ & 0.0002 & $\mathrm{ND}^{*}$ & $\mathrm{ND}$ \\
Total $\mathrm{Zn}(\%)$ & 0.0023 & 0.0087 & 0.0044 \\
Total $\mathrm{Cl}(\%)$ & - & 0.2500 & 0.1100 \\
Total S $(\%)$ & 0.0230 & 0.3500 & 0.3500 \\
\hline
\end{tabular}

*ND, Not detected; N, nitrogen; P, phosphorus; K, potassium; Na, sodium; Ca, calcium; Mg, magnesium; $\mathrm{Fe}$, iron; Mn, manganese; Cu, cupper; Zn, zinc; Cl, chlorine; S, sulphur.

$10 \mathrm{~g} \mathrm{l}^{-1}$ of glucose. However, the sugar consumption at $150 \mathrm{~g} \mathrm{I}^{-1}$ of glucose was only $80 \%$ of the initial value. Therefore, in this study, $100 \mathrm{~g} \mathrm{I}^{-1}$ of initial sugar concentration in the IP media was used to complete sugar utilization. The compositions of the IP media in Table 1 were then designed according to the typical YM medium (YM 1). In SSJ 2 and SSJ 5, DSY at $11 \mathrm{~g} \mathrm{I}^{-1}$ was used as a nutrient supplement to replace YE, ME and PE (at total amount of $11 \mathrm{~g} \mathrm{I}^{-1}$ ) in the YM1, whereas only half the amounts of the three nutrients were formulated in SSJ 3 and SSJ 6 in order to reduce the cost of IP media.

The time profiles of viable cell concentration during batch cultures of $S$. cerevisiae NP 01 in the IP media containing total sugar of 20 (YM 1, SSJ 1, SSJ 2 and SSJ 3) and $100 \mathrm{~g} \mathrm{I}^{-1}$ (YM 2, SSJ 4, SSJ 5 and SSJ 6) are shown in Figure 1. No lag phase was observed after the yeast cells were incubated into all media. This might be due to good adaptation of yeast cells to the new environment. The average cell numbers at the stationary phase of SSJ 1, 2 and 3 (the IP media containing $20 \mathrm{~g} \mathrm{I}^{-1}$ of total sugar) were not significantly different (Table 3 ). However, they were significantly different from that of the control (YM 1) $(p \leq 0.05)$ (Table 3). In the IP media containing the total sugar of $100 \mathrm{~g} \mathrm{I}^{-1}$, the SSJ 6 gave the highest cell numbers at the stationary phase $(\log 8.55 \pm$ 0.03 cells $\mathrm{ml}^{-1}$ ) and the viable cell concentrations of SSJ 4,5 and 6 were significantly higher than that of the control (YM 2) $\left(\log 8.13 \pm 0.04\right.$ cells $\left.\mathrm{ml}^{-1}\right)$.

Bai et al. (2008) reported that nitrogen was the most important component in the fermentation medium. Therefore, we used DSY as a low-cost nitrogen supplement. Phunjumpa et al. (2006) also reported that the yeast cell concentration increased 2.5 times of the control medium (without supplementation) when they were cultured in Melzoch media (Melzoch et al., 1991) and tamarind juice supplemented with $1 \mathrm{~g} \mathrm{I}^{-1}$ of DSY. However, in our experiment, under the same initial sugar concentration, the maximum viable cell concentrations of SSJ 2 and 5 (with DSY supplementation) were not different from those of SSJ 1 and 4 (without DSY supplementation) (Table 3). This finding implied that the SSJ contained sufficient essential nutrients for yeast growth.

When $\mu$ during log phase were calculated (Table 3 ), the lowest $\mu$ was observed in the YM 2, while $\mu$ in the other IP media were similar with a range of 0.36 to $0.41 \mathrm{~h}^{-1}$. The sugar utilization of $S$. cerevisiae NP 01 under various IP media was relatively high with at least $82 \%$ of the initial value (Table 3). The IP media containing $100 \mathrm{gl}^{-1}$ of total sugar gave higher maximum yeast cell concentration than those containing only $20 \mathrm{~g} \mathrm{I}^{-1}$ and the sugar was almost completely consumed in the former. These results indicate that the increase in total sugar in the IP media up to $100 \mathrm{~g} \mathrm{I}^{-1}$ led to an increase in the maximum cell concentration (Table 3).

The IP media containing higher sugar concentration gave higher maximum cell concentration and the aim of this experiment was to develop a low-cost IP medium; therefore, the SSJ containing $100 \mathrm{~g} \mathrm{I}^{-1}$ of total sugar without nutrient supplement (SSJ 4) was selected to be the IP medium for batch and repeated-batch ethanol fermentations.

\section{Batch ethanol fermentation}

To increase cell concentration, the yeast cells were cultured in the SSJ 4 medium at $30^{\circ} \mathrm{C}$ with the agitation rate of 150 rev $\min ^{-1}$ for $15 \mathrm{~h}$. The cells were then harvested and used as inoculum for ethanol production under the batch fermentation. Figure 2 shows the time 

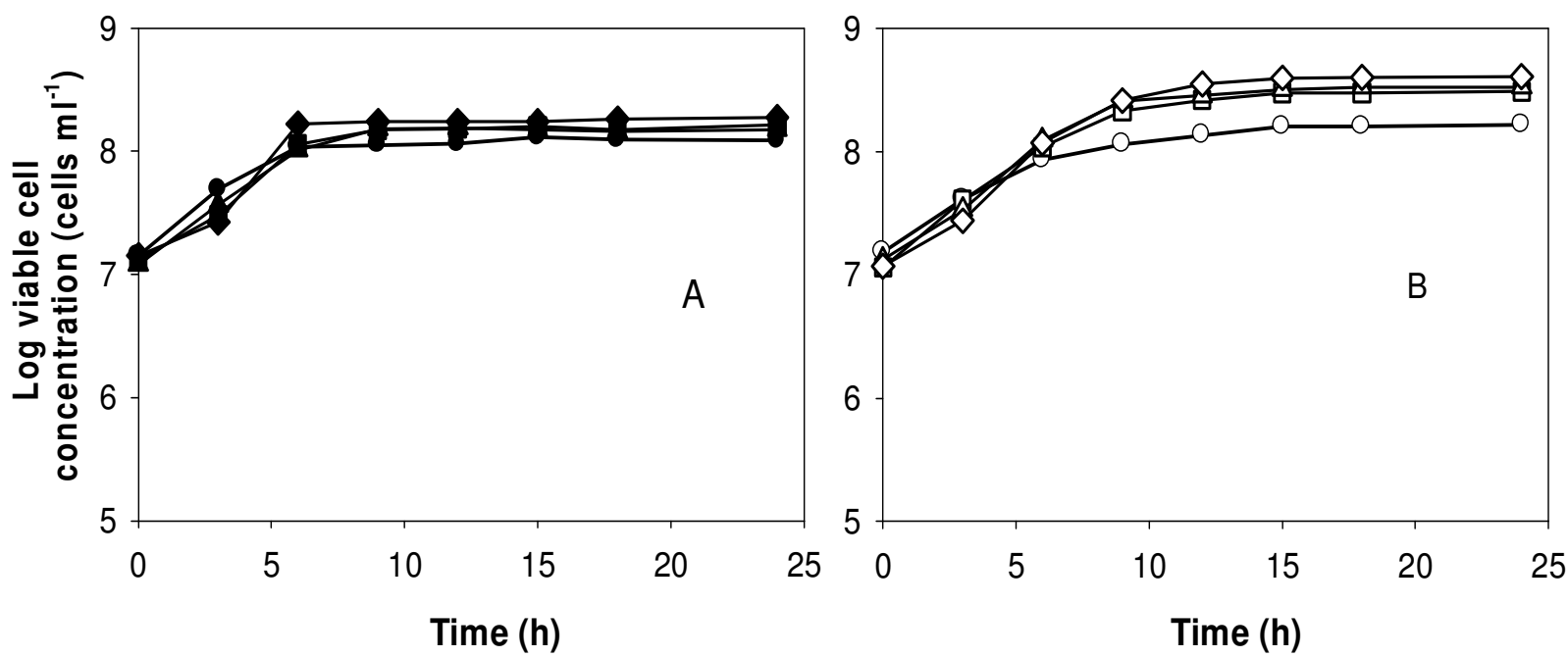

Figure 1. Growth curve of $S$. cerevisiae NP 01 in various IP media containing the total sugar concentration of 20 (A) and

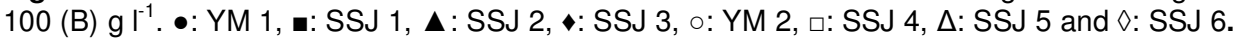

Table 3. Specific growth rate $(\mu)$ and sugar utilization of $S$. cerevisiae NP 01 in various IP media.

\begin{tabular}{|c|c|c|c|c|c|}
\hline \multirow{2}{*}{ Medium code ${ }^{\star}$} & \multirow{2}{*}{$\begin{array}{l}\text { Initial total sugar } \\
\text { concentration }\left(\mathrm{g} \mathrm{I}^{-1}\right)\end{array}$} & \multirow{2}{*}{$\mu\left(h^{-1}\right)$} & \multirow{2}{*}{$\begin{array}{c}\text { Sugar } \\
\text { Utilization (\%) }\end{array}$} & \multicolumn{2}{|c|}{ Log cell concentration (cell $\mathrm{ml}^{-1}$ ) } \\
\hline & & & & Initial & Stationary phase \\
\hline YM 1 (control 1) & \multirow{4}{*}{20} & $0.34 \pm 0.01$ & $93.63 \pm 0.35$ & $7.11 \pm 0.06$ & $8.05 \pm 0.03(9 h)^{\star \star}$ \\
\hline SSJ 1 & & $0.36 \pm 0.02$ & $92.62 \pm 0.57$ & $7.16 \pm 0.08$ & $8.17 \pm 0.03(9 \mathrm{~h})$ \\
\hline SSJ 2 & & $0.36 \pm 0.02$ & $82.14 \pm 0.40$ & $7.09 \pm 0.06$ & $8.17 \pm 0.08$ (9 h) \\
\hline SSJ 3 & & $0.41 \pm 0.02$ & $89.19 \pm 0.14$ & $7.17 \pm 0.06$ & $8.24 \pm 0.03(9 h)$ \\
\hline YM2 (control 2) & \multirow{4}{*}{100} & $0.28 \pm 0.00$ & $95.71 \pm 0.13$ & $7.32 \pm 0.06$ & $8.13 \pm 0.04(12 h)$ \\
\hline SSJ 4 & & $0.37 \pm 0.02$ & $92.22 \pm 0.11$ & $7.09 \pm 0.10$ & $8.42 \pm 0.04(12 h)$ \\
\hline SSJ 5 & & $0.37 \pm 0.02$ & $90.15 \pm 0.29$ & $7.12 \pm 0.04$ & $8.45 \pm 0.03(12 h)$ \\
\hline SSJ 6 & & $0.39 \pm 0.02$ & $91.53 \pm 0.00$ & $7.04 \pm 0.16$ & $8.55 \pm 0.03(12 h)$ \\
\hline
\end{tabular}

**, Fermentation time. The experiments were performed in duplicate and the results were expressed as mean \pm SD.

profiles of some main compositions during batch fermentation of S. cerevisiae NP 01 from the SSJ without nutrient supplementation. At the beginning of the fermentation, the initial total sugar, reducing sugar and total soluble solids in the SSJ were $228.80 \pm 3.07 \mathrm{~g} \mathrm{I}^{-1}, 158.41$ $\pm 4.82 \mathrm{~g} \mathrm{I}^{-1}$ and $24.4^{\circ} \mathrm{Bx}$, respectively. The $\mathrm{pH}$ of the broth was slightly decreased from 4.60 to 4.22 at $12 \mathrm{~h}$ and then constantly throughout the experiment (data not shown). This might be due to carbondioxide produced by S. cerevisiae NP 01 during fermentation that was formed to carbonic acid in the fermentation broth and then changed to carbonate ion and proton (Shen et al., 2004). The viable cell concentration was increased about 3 times from $1.06 \times 10^{8}$ cells ml ${ }^{-1}$ to $2.94 \times 10^{8}$ cells ml $^{-1}$ at 48 $\mathrm{h}$. The total sugar and reducing sugar levels were markedly decreased and almost depleted at $48 \mathrm{~h}$. The total sugar and reducing sugar remaining in the fermentation broth were $13.15 \pm 0.31$ and $3.95 \pm 0.06 \mathrm{gl}^{-1}$, respectively. In addition, $P$ was increased and reached the maximum value of $110.09 \pm 0.81 \mathrm{~g} \mathrm{I}^{-1}$ at $48 \mathrm{~h}$. The $Q_{p}$ and $Y_{p / s}$ were $2.29 \pm 0.01 \mathrm{~g} \mathrm{I}^{-1} \mathrm{~h}^{-1}$ and $0.51 \pm 0.02$, respectively.

\section{Effects of fill and drain volume on ethanol production in repeated-batch fermentation}

In the repeated-batch fermentation in the flask, the juice was withdrawn at 75 and $50 \%$ of the working volume, and the same amount of the fresh juice was immediately replaced. At the $75 \%$ fill and drain volume (Figure 3: 1A$1 \mathrm{E})$ in the first batch, the changes of total soluble solids, total sugar, reducing sugar, cell concentration and $\mathrm{pH}$ were similar to those found in the batch system. In batch 2 to 8 , the initial total soluble solids, total sugar and reducing sugar concentrations were lower than those in batch 1 because the fresh ethanol production medium added was diluted with the remaining medium in the 


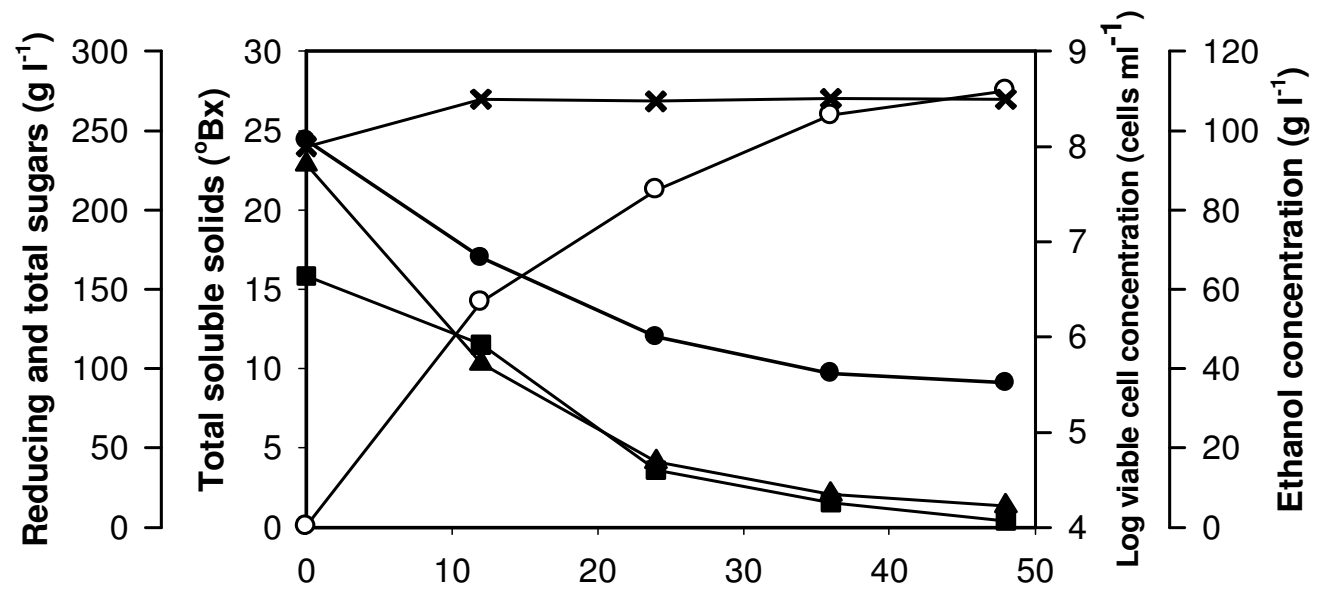

Time (h)

Figure 2. Batch culture profile of ethanol production from sweet sorghum juice containing the total soluble solids of $24^{\circ} \mathrm{Bx}(\bullet$, total soluble solids; $\boldsymbol{\Lambda}$, total sugar; $\mathbf{m}$, reducing sugar; $\mathbf{x}$, log viable cell concentration; $\circ$, ethanol concentration).

flask ( $25 \%$ of total working volume) and the fermentation time was increased to $60 \mathrm{~h}$. At the end of batch 2 to 8 , the viable cell concentrations were relatively constant with approximately $0.5 \mathrm{log}$ scale lower than that of batch 1 , while the ethanol concentrations ranged from $88.52 \pm$ 4.04 to $105.32 \pm 0.81 \mathrm{~g} \mathrm{l}^{-1}$. Lower $P$ in batch 2 to $8 \mathrm{might}$ be due to lower cell concentration in the broth when compared with those of the first batch. The total amount of ethanol was $237.13 \mathrm{~g}$ in $2.5 \mathrm{~L}$ of the fermentation broth, and the total rate of ethanol production was $0.51 \mathrm{~g}$ $\mathrm{h}^{-1}$. The total fermentation time of the eight successive batches at $75 \%$ fill and drain was $468 \mathrm{~h}$. At the $50 \%$ fill and drain volume, the changes of parameters measured were similar to those of $75 \%$ fill and drain (Figure 3: $2 \mathrm{~A}$ $2 \mathrm{E})$. The total amount of ethanol was $161.70 \mathrm{~g}$ in $1.8 \mathrm{~L}$ of the fermentation broth, and the total rate of ethanol production was $0.39 \mathrm{~g} \mathrm{~h}^{-1}$. The total fermentation time of the eight successive batches was $420 \mathrm{~h}$.

The average ethanol production efficiencies of the eight successive batches are summarized in Table 4. $P, Q_{p}$ and $Y_{p / s}$ of the fermentation with 75 and $50 \%$ fill and drain were not significantly different $(p<0.05)$. However, the total rates of ethanol production at $75 \%$ fill and drain $\left(0.51 \mathrm{~g} \mathrm{~h}^{-1}\right)$ was higher than that of $50 \%$ fill and drain $\left(0.39 \mathrm{~g} \mathrm{~h}^{-1}\right)$. This might be because the amount of fermented broth being removed at $75 \%$ fill and drain was more than that of $50 \%$ fill and drain. This caused the ethanol in the broth at the beginning of each batch to be more diluted, which might prevent or reduce the product inhibition effect that might occur. Therefore, $75 \%$ fill and drain was selected for repeated-batch fermentation in the next experiment.

The results obtained from this study were similar to those of Choi et al. (2009) who reported that higher fill and drain volume (20\%) gave higher $P$ and cell concentration when compared with the lower fill and drain volumes (5 and 10\%). However, they found that the decrease in the fill and drain volume gave higher $Q_{p}$. Chen et al. (2008) indicated that the initial cell concentration affected $P$ and $Q_{p}$ in repeated-batch fermentation using free cells. The contradictory result was observed by immobilized cells. Staniszewski et al. (2009) reported that the decrease in the fill and drain volume in repeated-batch fermentation by immobilized cells gave a slight increase in $P$.

\section{Repeated-batch ethanol fermentation in the bioreactor}

The profiles of the main compositions during the repeated-batch fermentation in the $2 \mathrm{~L}$ bioreactor at $75 \%$ fill and drain were the same as those in the flask (data not shown). The ethanol production efficiencies of each batch in the bioreactor are summarized in Table 5 . The average $P, Q_{p}$ and $Y_{p / s}$ of the eight successive batches in the bioreactor were similar to those in the flask with the values of $93.30 \pm 9.44 \mathrm{~g} \mathrm{l}^{-1}, 1.21 \pm 0.43 \mathrm{~g} \mathrm{l}^{-1} \mathrm{~h}^{-1}$ and $0.48 \pm 0.03$, respectively. Total ethanol production of the eight successive batches was $851.98 \mathrm{~g}$ ethanol in 10.25 $\mathrm{L}$ of the fermentation broth, and the rate of ethanol production was $1.82 \mathrm{~g} \mathrm{~h}^{-1}$ with the total fermentation time of $468 \mathrm{~h}$. Because of our limitation in the raw materials, only eight repeated-batches were performed in this study. More successive batches (16 cycles) of repeated-batch ethanol fermentation from sweet sorghum was reported by Chohnan et al. (2011). However, the working volume used in each cycle was $10 \mathrm{ml}$ only. Ozmihci and Kargi 

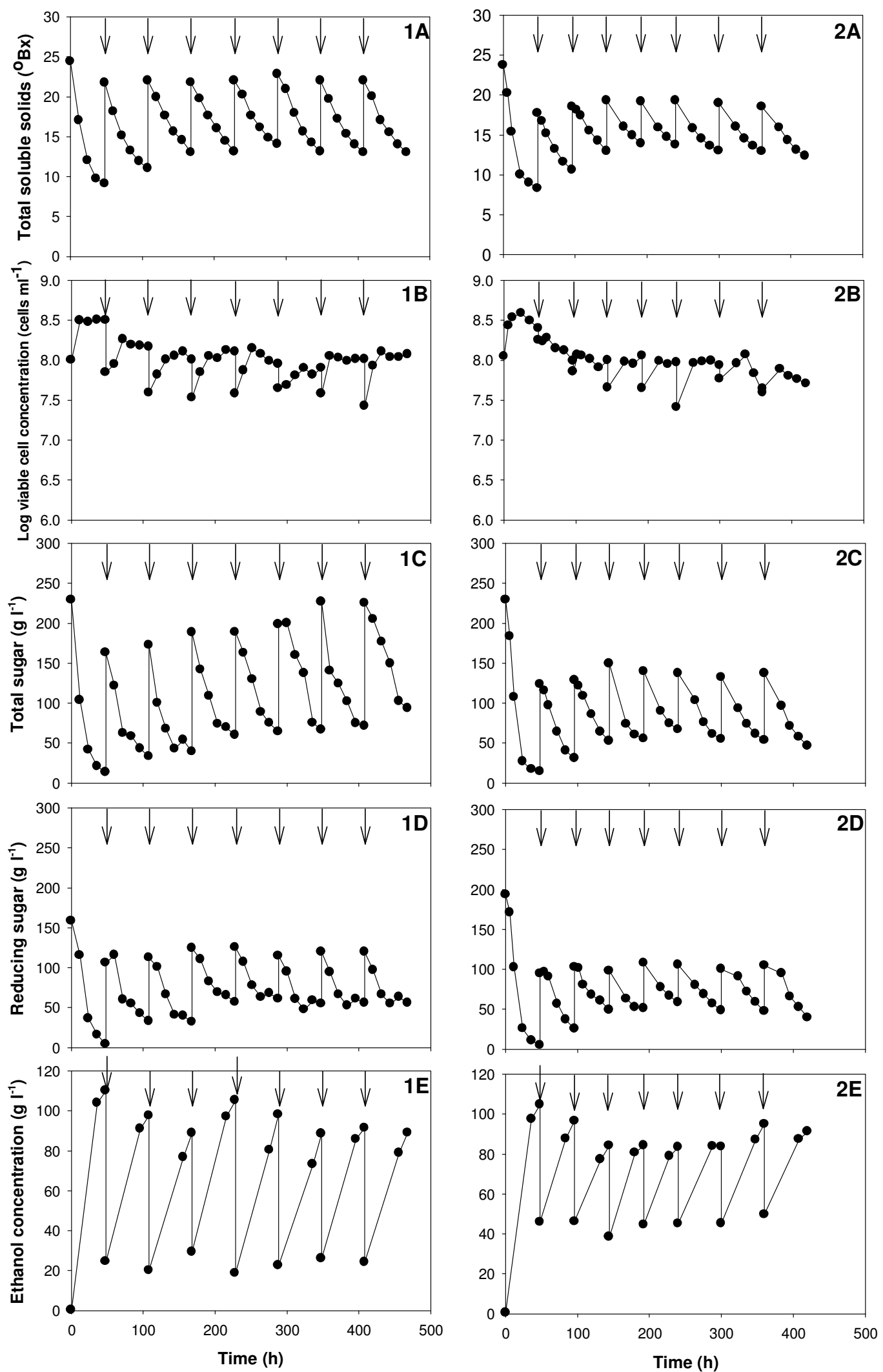

Figure 3. Repeated-batch ethanol fermentation at $75 \%$ fill and drain from sweet sorghum juice containing the total soluble solids of $24{ }^{\circ} \mathrm{Bx}$ in the $500 \mathrm{ml}$ air-locked flask (A, total soluble solids; $\mathrm{B}$, log viable cell concentration; C, total sugar; D, reducing sugar; $\mathrm{E}$, ethanol concentration). The arrows indicate the start time of each batch. 
Table 4. Comparison kinetic parameters of ethanol production from sweet sorghum juice by $S$. cerevisiae NP 01 using repeated-batch fermentation at different fill and drain volumes in the $500 \mathrm{ml}$ flask.

\begin{tabular}{|c|c|c|c|c|c|c|}
\hline \multirow{3}{*}{ Batch number } & \multicolumn{6}{|c|}{ Parameter (mean $\pm S D)^{\star}$} \\
\hline & \multicolumn{3}{|c|}{$75 \%$ fill and drain } & \multicolumn{3}{|c|}{$50 \%$ fill and drain } \\
\hline & $P\left(\mathrm{~g} \mathrm{I}^{-1}\right)$ & $Q_{p}\left(\mathrm{~g} \mathrm{I}^{-1} \mathrm{~h}^{-1}\right)$ & $Y_{p / s}\left(\mathrm{~g} \mathrm{~g}^{-1}\right)$ & $P\left(\mathrm{~g} \mathrm{I}^{-1}\right)$ & $Q_{p}\left(\mathrm{~g} \mathrm{I}^{-1} \mathrm{~h}^{-1}\right)$ & $Y_{p / s}\left(\mathrm{~g} \mathrm{~g}^{-1}\right)$ \\
\hline 1 & $109.08 \pm 0.71$ & $2.27 \pm 0.02$ & $0.51 \pm 0.02$ & $104.69 \pm 0.13$ & $2.18 \pm 0.01$ & $0.51 \pm 0.00$ \\
\hline 2 & $97.55 \pm 0.24$ & $1.22 \pm 0.01$ & $0.53 \pm 0.00$ & $96.47 \pm 0.79$ & $1.05 \pm 0.02$ & $0.53 \pm 0.00$ \\
\hline 3 & $88.87 \pm 3.99$ & $1.15 \pm 0.06$ & $0.51 \pm 0.02$ & $84.19 \pm 0.77$ & $0.79 \pm 0.05$ & $0.50 \pm 0.00$ \\
\hline 4 & $105.32 \pm 0.81$ & $1.27 \pm 0.00$ & $0.53 \pm 0.00$ & $84.25 \pm 1.70$ & $0.95 \pm 0.04$ & $0.49 \pm 0.01$ \\
\hline 5 & $98.08 \pm 3.74$ & $1.32 \pm 0.07$ & $0.53 \pm 0.00$ & $83.42 \pm 0.41$ & $0.81 \pm 0.01$ & $0.53 \pm 0.03$ \\
\hline 6 & $88.52 \pm 4.04$ & $1.04 \pm 0.11$ & $0.45 \pm 0.03$ & $83.58 \pm 0.07$ & $0.64 \pm 0.04$ & $0.47 \pm 0.03$ \\
\hline 7 & $91.38 \pm 5.07$ & $1.09 \pm 0.09$ & $0.45 \pm 0.02$ & $94.90 \pm 0.75$ & $0.83 \pm 0.03$ & $0.53 \pm 0.00$ \\
\hline 8 & $88.97 \pm 1.93$ & $1.08 \pm 0.06$ & $0.45 \pm 0.01$ & $91.20 \pm 1.61$ & $0.69 \pm 0.05$ & $0.46 \pm 0.03$ \\
\hline average & $95.97 \pm 7.95$ & $1.30 \pm 0.41$ & $0.50 \pm 0.04$ & $90.34 \pm 7.87$ & $0.99 \pm 0.49$ & $0.50 \pm 0.03$ \\
\hline
\end{tabular}

${ }^{*} P, Q_{p}$ and $Y_{p / s}$, Ethanol concentration, ethanol productivity and ethanol yield of the eight successive batches, respectively.

Table 5. Kinetic parameters of ethanol production from sweet sorghum juice by $S$. cerevisiae NP 01 using repeated-batch fermentation at $75 \%$ fill and drain in the $2 \mathrm{~L}$ bioreactor.

\begin{tabular}{cccc}
\hline \multirow{2}{*}{ Batch number } & \multicolumn{3}{c}{ Parameter $\left(\mathbf{m e a n}^{-1} \mathbf{S D}\right)^{\star}$} \\
\cline { 2 - 4 } & $\boldsymbol{P}\left(\mathbf{g ~ l}^{-1}\right)$ & $\boldsymbol{Q}_{\boldsymbol{p}}\left(\mathbf{g ~ I}^{-1} \mathbf{h}^{-1}\right)$ & $\boldsymbol{Y}_{\boldsymbol{p} / \mathbf{s}}\left(\mathbf{g ~ g}^{-1}\right)$ \\
\hline 1 & $108.95 \pm 0.57$ & $2.25 \pm 0.01$ & $0.53 \pm 0.01$ \\
2 & $105.22 \pm 2.02$ & $1.25 \pm 0.03$ & $0.53 \pm 0.00$ \\
3 & $96.86 \pm 1.26$ & $1.13 \pm 0.04$ & $0.47 \pm 0.01$ \\
4 & $91.25 \pm 0.00$ & $1.05 \pm 0.00$ & $0.47 \pm 0.04$ \\
5 & $88.56 \pm 0.75$ & $1.05 \pm 0.00$ & $0.48 \pm 0.01$ \\
6 & $85.08 \pm 0.20$ & $0.94 \pm 0.06$ & $0.47 \pm 0.02$ \\
7 & $85.53 \pm 1.40$ & $1.01 \pm 0.05$ & $0.47 \pm 0.03$ \\
8 & $84.94 \pm 0.10$ & $1.03 \pm 0.01$ & $0.46 \pm 0.01$ \\
average & $93.30 \pm 9.44$ & $1.21 \pm 0.43$ & $0.48 \pm 0.03$ \\
\hline
\end{tabular}

* $P, Q_{p}$ and $Y_{p / s}$, Ethanol concentration, ethanol productivity and ethanol yield of the eight successive batches, respectively.

(2007) studied ethanol production from cheese whey powder solution at sugar concentration of $125 \mathrm{~g} \mathrm{l}^{-1}$ using repeated fed-batch fermentation. The total working volume was $5 \mathrm{~L}$. They found that high ethanol production rate in five cycles $\left(5.3 \mathrm{~g} \mathrm{~h}^{-1}\right)$ was obtained at the total fermentation time of $336 \mathrm{~h}$. The higher ethanol production rate as compared with that of our study might be due to the differences in microorganism, working volume and initial sugar concentration. The initial sugar at higher concen-trations significantly retarded the ethanol production rate (Laopaiboon et al., 2008). In our study, the initial sugar concentration was about 2 times higher than that reported by Ozmihci and Kargi (2007).

Table 6 compares the ethanol fermentation by repeated-batch process from various low-cost raw materials. It is clearly shown that the SSJ is one of the candidate raw materials for scale-up ethanol production. In this study, the $P, Q_{p}$ values in batch 2 to 8 were lower than those in batch 1. To improve the ethanol production efficiencies, cell recycling (Choi et al., 2009) or cell immobilization (Yu et al., 2007) should be considered to increase the initial cell concentration in the subsequent batches.

\section{Conclusion}

The SSJ containing $100 \mathrm{~g} \mathrm{I}^{-1}$ of total sugar without any nutrient supplement (SSJ 4 medium) could be used directly as a low-cost IP medium instead of the typical or YM medium. The use of this IP medium can significantly reduce both the cost and preparation time. Ethanol production from SSJ by $S$. cerevisiae NP 01 using repeated-batch fermentation could be carried out at least eight successive batches. The fill and drain volume in the repeated-batch system did not affect the ethanol 
Table 6. Ethanol production from various low-cost raw materials using repeated-batch fermentation.

\begin{tabular}{|c|c|c|c|c|c|}
\hline Raw material & $\begin{array}{c}\text { Working } \\
\text { volume of each } \\
\text { cycle }(L)\end{array}$ & $\begin{array}{c}\text { Fill and } \\
\text { drain } \\
\text { volume (\%) }\end{array}$ & $\begin{array}{l}\text { Number } \\
\text { of cycle }\end{array}$ & $P^{*}\left(\mathrm{~g} \mathrm{I}^{-1}\right)$ & Reference \\
\hline Molasses medium (25\% w/v) & 3.0 & 75 & 6 & 106 & Kida et al. (1991) \\
\hline Molasses medium $(22 \% \mathrm{w} / \mathrm{v})$ & 3.0 & 75 & 6 & 92 & Morimura et al. (1997) \\
\hline Cheese whey powder $\left(125 \mathrm{~g} \mathrm{l}^{-1}\right)$ & 5.0 & 60 & 5 & 63 & Ozmihci and Kargi (2007) \\
\hline Casava medium (185 $\mathrm{gl}^{-1}$ of sugar) & 4.0 & 20 & 10 & 85 & Choi et al. (2009) \\
\hline Kitchen refuse ( $130 \mathrm{gl}^{-1}$ of sugar) & $<1$ & 60 & $>10$ & 80 & Ma et al. (2009) \\
\hline Sweet sorghum juice (100 $\mathrm{gl}^{-1}$ of sugar) & 0.01 & 100 & 16 & $44-48$ & Chohnan et al. (2011) \\
\hline Sweet sorghum juice (230 $\mathrm{gl}^{-1}$ of sugar) & 1.5 & 75 & 8 & 93 & This study \\
\hline
\end{tabular}

${ }^{*} \boldsymbol{P}$, Ethanol concentration.

production efficiencies in terms of $P, Q_{p}$ and $Y_{p / s}$ However, higher fill and drain volume gave higher total ethanol production rate $\left(\mathrm{g}\right.$ ethanol $\left.\mathrm{h}^{-1}\right)$ than the lower volume.

\section{ACKNOWLEDGEMENT}

This research was financially supported by the Fermentation Research Center for Value Added Agricultural Products (FerVAAP), Khon Kaen University, Thailand. We would like to thank Assistant Prof. Dr. Paiboon Danviruthai, Faculty of Technology, Khon Kaen University (KKU) for providing the NP01 strain, Beerthip Brewery (1991) Co., Ltd., Bang Baan, Phra Nakhon Sri Ayutthaya, Thailand for providing the DSY and Associate Prof. Dr. Aroonwadee Chanawong, Faculty of Associated Medical Sciences, KKU and Dr. Preekamol Klanrit, Faculty of Technology, KKU for their internal reviews of this paper and helpful suggestions.

\section{REFERENCES}

Akao S, Tusno H, Cheon J (2007). Semi-continuous L-lactate fermentation of garbage without sterile condition and analysis of the microbial structure. Water Res. 41: 1774-1780.

Anastassiadis S, Rehm HJ (2006). Citric acid production from glucose by yeast Candida oleophila ATCC 20177 under batch continuous and repeated batch cultivation. Eletron. J. Biotechnol. 9: 26-39.

Almodares A, Hadi MR, Ranjbar M, Taheri R (2007). The effects of nitrogen treatments, cultivars and harvest stages on stalk yield and sugar content in sweet sorghum. Asian J. Plant Sci. 6: 423-426.

Bai FW, Anderson WA, Moo-Young M, (2008). Ethanol fermentation technologies from sugar and starch feedstocks. Biotechnol. Adv. 26: 89-105.

Bailey MJ (1988). A note on the use of dinitrosalicylic acid for determining the products of enzymatic reactions. Appl. Microbiol. Biotechnol. 29: 494-496.

Bajpai P, Bajpai PK (1988). Repeated fed batch fermentation for single cell protein production from prehydrolysate of a Pulp Mill. Enzyme Microb. Technol. 10: 280-284.

Bennett AS, Anex RP (2009). Production transportation and milling costs of sweet sorghum as a feedstock for centralized bioethanol production in the upper Midwest. Bioresour. Technol. 100: 1595-
1607.

Bryan WL (1990). Solid state fermentation of sugars in sweet sorghum. Enzyme Microb. Technol. 12: 437-442.

Chen JP, Wu KW, Fukuda H (2008). Bioethanol production from uncooked raw starch by immobilized surface-engineered yeast cells. Appl. Biochem. Biotechnol. 145: 59-67.

Choi GW, Kang HW, Moon SK (2009). Repeated-batch fermentation using flocculent hybrid Saccharomyces cerevisiae CHFY0321 for efficient production of bioethanol. Appl. Microbiol. Biotechnol. 84: 261-269.

Chohnan S, Nakane M, Rahman MH, Nitta Y, Yoshiura T, Ohta H, Kurusu $Y$ (2011). Fuel ethanol production from sweet sorghum using repeated-batch fermentation. J. Biosci. Bioeng. 111: 433-436.

Dajue L (2010). Sweet sorghum. In: Bassam NE editor. Handbook of Bioenergy Crops: A complete reference to species development and applications. Earthscan, London, UK.

Department of Energy Business, Ministry of Energy, Thai Government. Energy Statistics. [cited 30 January 2010]. Available from Internet: http//www.eppo.go.th/info/in.dex.html.

Ferreira IMPLVO, Pinh O, Vieira E, Tavarela JG (2010). Brewer's Saccharomyces yeast biomass: characteristics and potential applications. Trends Food Sci. Tech. 21: 77-84.

Göksungur Y, Zorlu N (2001). Production of ethanol from beet molasses by $\mathrm{Ca}$-alginate immobilized yeast cells in a packed-bed bioreactor. Turk J. Biol. 25: 265-275.

Ikegami T, Yamada Y, Ando H (1998). Acceleration of yeast growth by addition of carbon to cultivation medium. Biotechnol. Lett. 20: 673677.

Jiang M, Chen K, Liu Z, Wei P, Ying $H$, Chang $H$ (2009). Succinic acid production by Actinobacillus succinogenes using spent brewer's yeast hydrolysate as a nitrogen source. Appl. Biochem. Biotechnol. 160: 244-254.

Laopaiboon L, Thanonkeo P, Jaisil P, Laopaiboon P (2007). Ethanol production from sweet sorghum juice in batch and fed-batch fermentations by Saccharomyces cerevisiae. World J. Microbiol. Biotechnol. 23: 1497-1501.

Laopaiboon L, Nuanpeng S, Srinophakun P, Klanrit P, Laopaiboon P (2008). Selection of Saccharomyces cerevisiae and investigation of its performance for very high gravity ethanol fermentation. Biotechnology, 7: 493-498.

Laopaiboon L, Nuanpang S, Srinophakun P, Klanrit P, Laopaiboon P (2009). Ethanol production from sweet sorghum juice using very high gravity technology: Effects of carbon and nitrogen supplementations. Bioresour. Technol. 100: 4176-4182.

Liu H, Lin JP, Cen PL, Pan YJ (2004). Co-production of S-adenosyl-Imethionine and glutathione from spent brewer's yeast cells. Process Biochem. 39: 1993-1997.

Ma K, Wakisaka M, Sakai K, Shirai Y (2009). Flocculation characteristics of an isolated mutant flocculent Saccharomyces cerevisiae strain and its application for fuel ethanol production from 
kitchen refuse. Bioresour. Technol. 100: 2289-2292.

Marica R, Maja V, Slavica SM, Milan M (2007). Contribution of lactic acid fermentation to improved nutritive quality vegetable juiced enriched with brewer's yeast autolysate. Food Chem. 100: 599- 602.

Mecozzi M (2005). Estimation of total carbohydrate amount in environmental samples by the phenol-sulphuric acid method assisted by multivariate calibration. Chemometr. Intell. Lab. Syst. 79: 84-90.

Melzoch K, Rychtera M, Markvichov NS, Pospíchalavá V, Basařová G, Manakov MN (1991). Application of a membrane recycle bioreactor for continuous ethanol production. Appl. Microbiol. Biotechnol. 34: 469-472.

Narendranath NV, Power R (2005). Relationship between $\mathrm{pH}$ and medium dissolved solids in terms of growth and metabolism of Lactobacilli and Saccharomyces cerevisiae during ethanol production. Appl. Environ. Microbiol. 71: 2239-2243.

Ozmihci S, Kargi F (2007). Ethanol fermentation of cheese whey powder solution by repeated fed-batch operation. Enzyme Microb. Technol. 41: 169-174.

Phunjumpa J, Voraputhaporn W, Laopaiboon P, Danvirutai P (2006). Production of particulate yeast cell wall products and their potential commercial applications. Master Thesis in Biotechnology, Graduate School, Khon Kaen University.

Poggi Varaldo HM, Escamilla-Alvarado C, Esparza-García FJ, RíosLeal E, Ponce-Noyola MT, Rinderknecht-Seijas NF (2009). Semicontinuous biohydrogen production by solid substrate fermentation of organic wastes. New Biotechnol. 25: p. 253.

Rajvanshi AK, Nimbkar N (2005). Sweet sorghum R\&D at the Nimbkar Agriculture Research Institute (NARI). http://nariphaltan.virtualave.net/sorghum.htm. Accessed 25 January 2011.

Rivas B, Moldes AB, Dominguez JM, Parajo JC (2004). Development of culture media containing spent yeast cells of Debaryomyces hansenii and corn steep liquor for lactic acid production with Lactobacillus rhamnosus. Int. J. Food Microbiol. 97: 93-98.

Rudolf A, Karhumaa K, Hahn-Hägerdal, B (2009) Ethanol Production from Traditional and Emerging Raw Materials, In: Yeast Biotechnology: Diversity and Applications, DOI: 10.1007/978-1-40208292-4_23. pp. 489-513.

Saksinchai S, Suphantharika M, Verduyn C (2001). Application of a simple yeast extract from spent brewer's yeast for growth and sporulation of Bacillus thuringiensis subsp. Kurstaki: a physiological study. World J. Microbiol. Biotechnol. 17: 307-316.

Sombutyanuchit $P$, Suphantharika M, Verduyn C (2001). Preparation of 5'-GMP-rich yeast extracts from spent brewer's yeast. World J. Microbiol. Biotechnol. 17: 162-168.

Shen HY, Schrijver SD, Moonjai N, Verstrepen KJ, Delvaux F, Delvaux FR (2004). Effect of $\mathrm{CO}_{2}$ on the formation of flavor volatiles during fermentation with immobilized brewer's yeast. Appl. Microbiol. Biotechnol. 64: 636-643.
Sridee W, Laopaiboon P, Laopaiboon L (2009). Ethanol production from sweet sorghum stem juice under very high gravity conditions: Effects of dried spent brewer's yeast and scale up production. In: $21^{\text {st }}$ Annual Meeting of the Thai Society for Biotechnology, Biotechnology: Biotechnology: A Solution for the Global Economics Crisis?. Sep 2425, 2009, Bangkok, Thailand.

Staniszewski M, Kujawski W, Lewandowska M (2009). Semi-continuous ethanol production in bioreactor from whey with co-immobilized enzyme and yeast cells followed by pervaporative recovery of product - Kinetic model predictions considering glucose repression. J. Food Eng. 91: 240-249.

Tanguler H, Erten $\mathrm{H}$ (2008). Utilisation of spent brewer's yeast for yeast extract production by autolysis: The effect of temperature. Food Bioprod. Process. 86: 317-321.

Wu X, Jiang S (2009). Production of L-lactic acid by Rhizopus oryzae using semi-continuous fermentation. New Biotechnol. 25: p. 194.

Wu X, Staggenborg S, Propheter JL, Rooney WL, Yu J, Wang D (2010). Features of sweet sorghum juice and their performance in ethanol fermentation. Ind. Crop. Prod. 31: 164-170.

York SW, Ingram LO (1996). Ethanol production by recombinant Escherichia coli KO11 using crude yeast autolysate as a nutrient supplement. Biotechnol. Lett. 18: 683-688.

Yu J, Zhang X, Tan T (2007). An novel immobilization method of Saccharomyces cerevisiae to sorghum bagasse for ethanol production. J. Biotechnol. 129: 415-420.

Zoecklien BW, Fugelsang KC, Gump BH, Nury FS (1995). Wine analysis and production. Chapman \& Hall, New York, USA.

Zvidzai C, Muzhinji N, Chidzvondo F, Mundembe R, Sithole-Niang I (2007). Potential commercialization of a microbial medium formulated from industrial food waste. Afr. J. Microbiol. Res. 1: 79-87. 